\title{
MEMÓRIAS DO LUGAR PARA O PERSONAGEM MI- GUILIM EM CAMPO GERAL, DE GUIMARÃES ROSA
}

\author{
Regina da Costa da Silveira \\ Ana Denise Teixeira Andrade \\ (UniRitter)
}

\section{RESUMO}

O presente artigo traz uma reflexão a respeito da construção da memória de uma personagem infantil, em uma narrativa de ficção, influenciada pelas memórias coletivas de seus familiares e agregados. A leitura do conto Campo Geral (2001), de João Guimarães Rosa, motiva tal discussão, tendo em vista que o protagonista, com o nome de Miguilim, é um menino sensível que se apoia em suas percepções sensoriais e nos relatos dos que com ele convivem para edificar a sua própria memória e para se iniciar na compreensão do meio em que vive. É através dos sinais externos, do espaço e da memória coletiva que a personagem constrói e desconstrói a sua estória e a de sua família. O protagonista convoca as lembranças para criar um elo entre as suas sensações e a realidade que o cerca, ainda que sejam recordações oriundas de uma mente demasiadamente jovem e, por isso mesmo, pouco experiente. A fim de compreender a formação da memória, nessa fase da vida, faz-se necessário o suporte teórico dos autores Iván Izquierdo (2011), que trata da memória sob a perspectiva da neurociência, Alan Baddeley (2011) e seus colaboradores, que pesquisam sobre a formação da memória e Maurice Halbwachs (2015), que relaciona a aquisição da memória ao contexto social. Além desses estudiosos, pesquisadores como Doreen Massey (2008) e Gaston Bachelard (s/d) também contribuem com seus estudos, ao refletir sobre a importância do lugar e do espaço. Através desse entrelaçamento de teorias, pode-se vislumbrar algumas formas de aquisição e conservação da lembrança infantil.

PALAVRAS-CHAVE: Sentidos; espaço; lugar; memória individual e coletiva; Campo Geral. 


\section{INTRODUÇÃO}

A capacidade de memorização acompanha a maioria dos indivíduos desde o nascimento, mas essas lembranças acabam sofrendo prejuízos em sua conservação, distorcidas pela passagem do tempo e pela oscilação emocional, porque as memórias, de acordo com Iván Izquierdo (2011, p. 14), "são moduladas pelas emoções, pelo nível de consciência e pelos estados de ânimo". Também, além desses fatores físicos e emocionais, outro ponto que concorre para interferir nesse processo de aquisição e armazenamento das lembranças são as memórias coletivas. Essas, quando associadas a todo um contexto social e cultural, têm o poder de atingir o desenvolvimento inato da memória em formação, principalmente em uma mente infantil e sem experiência. É o caso do protagonista Miguilim, da novela Campo Geral, de João Guimarães Rosa. Nessa estória, que se passa no Mutúm, encontra-se uma família que coabita um espaço humilde, com poucos recursos materiais e que cultiva tradições religiosas e crendices populares. Nesse meio, desenvolve-se um menino de oito anos, que procura construir suas memórias, também, por intermédio de seus sentidos, que são aguçados ao menor contato com uma nova realidade. Assim, é pela observação do espaço em que habita, mas, principalmente, valendo-se da companhia e das lembranças dos familiares e agregados da casa, que essa personagem consegue edificar a sua própria memória individual, pois, de acordo com Maurice Halbwachs,

é difícil encontrar lembranças que nos levem a um momento em que nossas sensações eram apenas reflexos dos objetos exteriores, em que não misturássemos nenhuma das imagens, nenhum dos pensamentos que nos ligavam a outras pessoas e aos grupos que nos rodeavam. Não nos lembramos de nossa primeira infância porque nossas impressões não se ligam a nenhuma base enquanto ainda não nos tornamos um ser social. $(2015$, p. 43)

Algumas lembranças remontam aos primeiros anos do protagonista Miguilim e, por ser uma fase em que a criança apresenta vocabulário ainda restrito, essas memórias não podem ser totalmente traduzidas em palavras, bem como não há uma completa interação com o mundo adulto. Outro aspecto a ser considerado é que a personagem principal, estando ainda em tenra idade, quase tudo o que recorda sofre, em grande parte, a influência de outrem. Entretanto, mesmo um pouco mais velho, por volta dos sete e oito anos de idade, não significa dizer que suas lembranças não 
sofressem interferências ou tão pouco fossem influenciadas por agentes externos. Toda e qualquer atividade de armazenamento e evocação da memória sofre influência do espaço. Seja oriunda da memória coletiva, que se confunde com a do protagonista, ou com os cinco sentidos, que são importantes nesse processo de edificação das lembranças, mas os próprios espaços por onde Miguilim transitou mostram-se decisivos para compor o quadro da memória.

Um lugar, em especial, é a própria moradia, espaço impregnado de emoções, infortúnios, religiosidade e de estórias familiares. Para Gaston Bachelard (s/d, p.22), "a casa é nosso canto do mundo. Ela é, como se diz frequentemente, nosso primeiro universo". Essa tendência de se associar a palavra lugar a um ambiente de aconchego, familiaridade, também faz parte do pensamento de Doreen Massey, que percebe o "lugar como algo fechado, coerente, integrado, como autêntico, como 'lar', um refúgio seguro" (2008, p. 25). Mas não é essa a concepção que o protagonista tem a respeito do lugar onde vivia, pois, para Miguilim, "a mata, ali perto, quase preta, verde-escura, punha-lhe medo" (ROSA, 2001, p. 29). Entretanto, não era apenas a mata que em nada oferecia proteção ou amparo. Sua relação familiar, principalmente com o pai, era difícil. Inúmeros castigos eram aplicados a Miguilim, pelo próprio genitor, Béro, que dizia:

-"Este menino é um mal-agradecido. Passeou, passeou, todos os dias esteve fora de cá, foi no Sucurijú, e, quando retorna, parece que nem tem estima por mim, não quer saber da gente..." [...] Mas o pai ainda ralhou mais, e, como no outro dia era de domingo, levou o bando dos irmãozinhos para pescaria no córrego; e Miguilim teve de ficar em casa, de castigo. (ROSA, 2001, p. 29)

O tratamento dispensado aos filhos, pelo pai, não acontecia de forma igualitária para todos os descendentes. Certamente, as crianças apanhavam e eram punidas pelas suas más ações, mas existia um tratamento "diferenciado", quando se tratava de Miguilim, que jamais poderia esquecer tal discriminação. Ao tratar de memória e sociedade, Eclea Bosi afirma que "outros fatores interferem na memória, como o lugar que alguém ocupa na consideração de seu grupo de convivência diária, onde há desigualdade de pontos de vista, uma repartição desigual de apreço" (1999, p. 414), como a que acontecia entre a família do protagonista. Estava claro, pelo menos para o menino, que o pai não distribuía igualmente as mesmas atenções entre os filhos, pois tudo o que Miguilim fazia de errado tinha uma repercussão ainda maior. 
Em outra ocasião, o menino recordava mais um momento em que apanhara e fora colocado de castigo:

Diante do pai, que se irava feito um ferro, Miguilim não pôde falar nada, tremia e soluçava; e correu para a mãe, que estava ajoelhada encostada na mêsa, as mãos tapando o rosto. Com ela se abraçou. Mas dali já o arrancava o pai, batendo nele, bramando. Miguilim nem gritava, só procurava proteger a cara e as orelhas; o pai tirara o cinto e com ele golpeava-lhe as pernas, que ardiam, doíam como queimaduras quantas, Miguilim sapateando. Quando pôde respirar, estava posto sentado no tamborete, de castigo. E tremia, inteirinho o corpo. O pai pegara o chapéu e saíra. (ROSA, 2001, p. 36)

O espaço por onde transitava a família era um ambiente tomado de desassossego, de apreensão permanente. Existia, até mesmo, um lugar específico para o castigo, que era o tamborete. De lá, ninguém poderia sair, até um adulto dar a permissão. Era um local para "pensar", "refletir" sobre o ato praticado e, por isso mesmo, memorável. Nesse sentido, o texto refere-se às coisas lembradas. Segundo o filósofo Paul Ricoeur (2012, p. 57), “as 'coisas' lembradas são intrinsecamente associadas a lugares. E não é por acaso que dizemos, sobre uma coisa que aconteceu, que ela teve lugar", mesmo que este espaço esteja associado à punição, aos desafetos, como era a casa de Miguilim. E é exatamente nesse primeiro local de penoso convívio social, que essa criança tem a possibilidade de construir suas memórias, junto com seus parentes e conhecidos, mesmo em uma localidade tão isolada como a que eles moravam. Essa propriedade era um lugar de difícil acesso e os familiares estavam distantes de qualquer recurso material e no que diz respeito à saúde. Um ambiente que apresentava uma atmosfera, de certa forma, hostil e repressora, ao mesmo tempo em que o espaço era dotado de uma bela paisagem. Essa tinha sido a informação que Miguilim ouvira, certa vez, quando

da viagem, que durou dias, ele guardara aturdidas lembranças, embaraçadas em sua cabecinha. De uma, nunca pôde se esquecer: alguém, que já estivera no Mutúm, tinha dito: -"É um lugar bonito, entre morro e morro, com muita pedreira e muito mato, distante de qualquer parte; e lá chove sempre... (ROSA, 2001, p. 27)

Mas o menino, ainda que concordasse com o homem, não poderia opinar, "não porque ele mesmo Miguilim visse beleza no Mutúm - nem ele sabia distinguir o que era um lugar bonito e um lugar feio. Mas só pela maneira como o moço tinha falado: de longe, de leve, sem interesse 
nenhum" (ROSA, 2001, p. 29). Essas impressões a respeito dos parentes e do lugar onde vivia pertenciam a Miguilim, porque "temos com a casa e com a paisagem que a rodeia a comunicação silenciosa que marca nossas relações mais profundas" (BOSI, 1999, p. 442). Por isso, mesmo sofrendo com a insensibilidade do pai, amava e admirava sua mãe, assim como gostava de seus irmãos, especialmente o Dito. Também tinha uma relação de carinho e respeito com o tio Terêz. Tudo isso faz parte das lembranças de Miguilim e esses fatores, também, serviram de motivação para que o menino buscasse em suas lembranças motivos suficientes para continuar vivendo, ao mesmo tempo em que essa situação era capaz de provocar a imaginação de um jovem menino e as muitas estórias familiares.

\section{ESTÓRIAS DE MIGUILIM}

As lembranças da primeira infância são, normalmente, fragmentadas. Esse esquecimento ou amnésia infantil pode acontecer, porque a linguagem não está devidamente desenvolvida e, portanto,

não é fácil decidir se as crianças têm memórias autobiográficas "genuínas". As crianças pequenas geralmente têm habilidades de linguagem muito limitadas. Isso significa que, em geral, elas são muito boas em comunicar com precisão o que conseguem se lembrar de suas vidas. Como resultado, muitas vezes não está claro se a criança de fato entende que os eventos que ela descreve realmente ocorreram com ela. (EYSENCK, 2011, p.299)

A escassez dessas memórias também é percebida na fala de Miguilim, quando tem vaga recordação dos seus primeiros anos de vida e suas lembranças eram agradáveis:

Do Pau-Rôxo conservava outras recordações, tão fugidias, tão afastadas, que até formavam sonho. Umas moças, cheirosas, limpas, os claros risos bonitos, pegavam nele [...] Depois, na alegria do jardim, deixavam-no engatinhar no chão, meio àquele fresco das folhas, mas o lindo era o das frutinhas vermelhas [...] As frutas a gente comia. Mas a mãe explicava que aquilo não havia sido no Pau-Rôxo, e bem nas Pindaíbas-de-Baixo-e-de-Cima, a fazenda grande dos Barbóz, aonde tinham ido de passeio. (ROSA, 2001, p. 31)

O relato dessa experiência, em particular, revela que existe uma memória autobiográfica, isto é, Miguilim e a mãe recordam de um momento específico de suas vidas, ao mesmo tempo em que os relacionam a outras pessoas, com imagens e odores já conhecidos. Mas é necessária a 
evocação da memória semântica, pois ela representa o "conhecimento de mundo" (EYSENCK, 2011, p. 128). Em conjunto, esses tipos de memórias serviram para consolidar incidentes marcantes na vida de Miguilim, mas que precisou contar com a ajuda da mãe para garantir a exatidão de suas lembranças.

Outro episódio significativo na vida do protagonista, ainda em tenra idade, aconteceu quando a família ainda morava em um "lugar chamado Pau-Rôxo, na beira do Saririnhém. De lá, separadamente, se recordava de sumidas coisas, lembranças que ainda hoje o assustavam" (ROSA, 2001, p. 30). A causa dessa recordação que o amedrontava tinha sido um incidente entre Miguilim e um menino maior. Durante o desentendimento que houve entre eles, o garoto arremessou uma pedra na cabeça do personagem principal, que ficou ferido e sangrava. Em outra passagem igualmente infeliz, essa

lembrança se misturava com outra, de uma vez em que ele estava nú, dentro da bacia, e seu pai, sua mãe, Vovó Izidra e Vó Benvinda em volta; o pai mandava: - "Traz o trém..." Traziam o tatú, que guinchava, e com a faca matavam o tatú, para o sangue escorrer por cima do corpo dele para dentro da bacia. - "foi de verdade, Mamãe?" - ele indagara muito tempo depois; e a mãe confirmava: dizia que ele tinha estado muito fraco, saído de doença, e que o banho no sangue vivo do tatú fora para ele poder vingar. (ROSA, 2001, p. 30-31)

As situações relatadas puderam ser evocadas, pois "as pessoas costumam lembrar melhor e com mais detalhe os episódios ou eventos carregados de emoção" [...] e "nem mesmo assim a recordação desses eventos chega a ser perfeita: nas melhores memórias sempre há um grau de extinção" (IZQUIERDO, 2011, p. 91). Todos esses episódios fazem parte de uma memória coletiva, construída em comunidade. Sem a confirmação dos outros, especialmente de sua mãe, Miguilim não teria a certeza de que suas memórias eram reais ou completas, porque "recorremos a testemunhos para reforçar ou enfraquecer e também para completar o que sabemos de um evento sobre o qual já temos alguma informação, embora muitas circunstâncias a ele relativas permaneçam obscuras" (HALBWACHS, 2015, p. 29).

A memória coletiva, em particular à da família de Miguilim, é construída a partir da "simultaneidade dessas diferentes estórias" (MASSEY, 2008, p. 36) e, ainda que não pertencessem à ficção, presentificando-se entre famílias que vivem realmente no interior brasileiro, não fazem parte 
da história oficial e, por isso mesmo, são negligenciadas e relegadas ao esquecimento. Trata-se de estórias particulares que são desvalorizadas e, por conseguinte, "inexistem", que não podem ou não necessitam ser contadas, até mesmo porque ficariam na "fila da história", uma vez que não fazem parte das ideias e das imagens veiculadas pela mídia. Para Doreen Massey, "a imaginação da globalização como uma sequência histórica não reconhece a coexistência simultânea de outras histórias com características que sejam distintas" (2008, p. 31). Entretanto, mesmo que as estórias não sejam reconhecidas, elas fazem parte do universo das comunidades e, mais precisamente, do imaginário na novela Campo Geral. E é dentro desse espaço, o da imaginação criadora do autor João Guimarães Rosa, que as estórias ganham força e se multiplicam, na memória de cada uma das personagens, principalmente quando Miguilim atinge uma certa idade e, por isso, consegue ter lembranças mais precisas do que lhe havia acontecido: "Miguilim tinha oito anos. Quando completara sete, havia saído dali, pela primeira vez: o tio Terêz levou-o a cavalo, à frente da sela, para ser crismado no Sucurijú, por onde o bispo passava" (ROSA, 2001, p. 27). Outra passagem significativa nas recordações do protagonista está relacionada aos sentidos, visto que o menino ficou deslumbrado quando se deparou com a indumentária do bispo:

Relembrável era o Bispo - rei para ser bom, tão rico nas cores daqueles trajes, até as meias dele eram vermelhas, com fivelas nos sapatos, e o anel, milagroso, que a gente não tinha tempo de ver, mas que de joelhos se beijava. (ROSA, 2001, p. 30)

A visão desempenha importante papel para a consolidação das memórias, já que "uma experiência visual penetra pela retina" (IZQUIERDO, 2011, p. 21), mas "costumamos traduzir imagens, conhecimentos e pessoas em palavras, e muitas vezes as guardamos como memórias só como tais" (IZQUIERDO, 2011, p. 21). Miguilim conseguia ver o mundo à sua maneira ainda mais distorcida, pois apresentava problemas de visão. Entretanto, nem ele ou sua família haviam percebido essa dificuldade e tratavam o assunto como mera distração. Em outras vezes, agiam até mesmo desprezando o menino, como é possível perceber nessas passagens do texto de Guimarães Rosa (2001):

Mas Miguilim não enxergava bem o toco, de certo porque estava com o bilhete no bolso, constante que em tio Terêz não queria pensar. (p. 87-88) 


\section{[...]}

Pai disse: -"Vigia, Miguilim: ali!" Miguilim olhou e não respondeu. Não estava vendo. Era uma plantação brotando da terra, lá adiante; mas direito ele não estava enxergando. Pai calou a boca, muitas vezes. Mas, de noite, em casa, mesmo na frente de Miguilim, Pai disse a Mãe que ele não prestava, que menino bom era o Dito, que Deus tinha levado para si, era muito melhor tivesse levado Miguilim em vez d'o Dito. (p. 130)

Nessa passagem, a dificuldade de enxergar agrava-se com o problema do desatino que lhe causa ter de esconder no bolso o bilhete escrito pelo Tio à sua mãe. $\mathrm{O}$ fato é que o protagonista, por mais que se esforçasse, jamais alcançava a aprovação do pai. Quando não eram surras, ouvia esses comentários desfavoráveis sempre a seu respeito. Miguilim sofria com o desafeto do genitor, mas também padeceu ainda mais, no momento em que seu irmão preferido, o Dito, falecera. Foi traumático para o menino ouvir as palavras de sua mãe:

-“Olha os cabelos bonitos dele, o narizinho...” - Mãe soluçava. "Como o pobre do meu filhinho era bonito..." Miguilim não aguentava ficar ali; foi para o quarto de Luisaltino, deitou na cama, tapou os ouvidos com as mãos e apertou os olhos no travesseiro - precisava de chorar, toda-a-vida, para não ficar sozinho. (ROSA, 2001, p. 120)

Novamente, o som da voz humana era capaz de ferir os sentimentos de Miguilim, só que, dessa vez, ouvia o lamentar de sua própria mãe, o que tornava a dor ainda maior. Também, porque a queixa referia-se a Dito. Daí a necessidade de fechar os ouvidos para o sofrimento, de tapar os olhos para a realidade. Chorar, naquela hora, era tudo o que lhe restava a fazer, num lugar impregnado pela tristeza e pela desunião. Já não existia o irmão querido e as lembranças de tudo que haviam vivenciado juntos, agora apenas faziam parte do passado. Viveria das memórias felizes dos momentos ao lado de Dito.

Muito embora o protagonista ouvisse inúmeras situações pesarosas e delas se recordasse bem, nem sempre suas lembranças enveredavam para o lado negativo da vida. Existiam momentos em que apreciava ouvir o som dos pássaros que capturava, das estórias da família e, especialmente, da voz da irmã que se chamava Chica e rezava alto diante do oratório, localizado no interior da casa. Para Miguilim, "era a voz mais bonita de todas" (ROSA, 2001, p. 48). Naquele lugar, os parentes reuniam-se du- 
rante as fortes tempestades ou quando necessitavam de um milagre.

No Mutúm chovia muito e, frequentemente, era assolado por fortes rajadas de vento. Em um desses episódios, no momento em que "tinha dado o vento, caíam uns pingos grossos, chuva quente [...] O vento zunia, queria carregar a gente. [...] Vento te leva... [...] $\mathrm{O}$ vento vuvo: viív...,viív..." (ROSA, 2001, p. 43), assustava, não somente as crianças, mas os adultos também. Nessas horas de tempestade, onde o vento derrubava árvores, penetrava pelas frestas da casa envelhecida onde a família morava e sentiam medo pelos estrondos do trovão, parentes e agregados lembravam-se de evocar sua fé para pedir proteção. A casa, devido ao seu mau estado de conservação, permitia que o vento e as chuvas entrassem naquele lugar e, dessa situação, Miguilim lembrava com exatidão:

Daí deu trovão maior, que assustava. O trovão da Serra do Mutúm-Mutúm, o pior do mundo todo, - que fosse como podia estatelar os paus da casa.

Corda-de-vento entrava pelas gretas das janelas, empurrava água. Molhava o chão. Miguilim e Dito a curto tinham olho no teto, onde o barulho remoía. A casa era muito envelhecida, uma vez o chuvão tinha desabado no meio do corredor, com um tapume do telhado. (ROSA, 2001, p. 44)

Miguilim tinha clara recordação do poder das tempestades e temia que ficassem desabrigados, que o telhado voasse pela força do vento. Isso aconteceu certa vez, que "chovera pela noite a fora, o vento arrancou telhas da casa. Ainda chovia, nem se podia pôr para secar o colchão de Tomezinho, que tinha urinado na cama" (ROSA, 2001, p. 51). A situação financeira precária em que viviam impedia que o pai fizesse as arrumações necessárias para que o lugar ficasse habitável. A miséria fazia parte da família e nem mesmo o telhado podia ser consertado. Isso significava dizer que estavam expostos às intempéries do tempo, pois, "o telhado revela sua razão de ser: cobre o homem que tem medo da chuva e do sol" (BACHELARD, s/d, p. 31).

Mas as crianças, em dado momento, pressentiram que a fúria da tempestade poderia estar relacionada ao desentendimento entre seus pais e o tio: "- Por causa de Mamãe, Papai e tio Terêz, Papai-do-Céu está com raiva de nós de surpresa..." (ROSA, 2001, p. 44). Essa recordação, certamente, estaria associada a estórias ouvidas, a crenças religiosas antigas, de que as tempestades representavam a ira de Deus, um castigo para os 
homens. Por isso a preocupação do menino, diante de um tempo adverso como aquele que se apresentava. A punição provável para a desavença familiar, segundo as crianças, justificava que a tempestade pudesse ser uma manifestação da cólera divina e, às vezes, um castigo, conforme $\mathrm{o}$ significado das tempestades na memória coletiva. $\mathrm{O}$ vendaval que assola o Mutúm, com fortes ventos que acompanham as tempestades, pode ser observado em seu significado simbólico. Jean Chevalier, no Dicionário de Símbolos, dirá que esses vendavais "também são instrumentos da força divina; dão vida, castigam, ensinam" (2015, p. 936). A crendice, a religiosidade e a superstição eram conhecimentos passados de geração a geração, e os meninos não estavam isentos de aprendê-los. Dada a exiguidade do espaço, as crianças assimilavam e colocavam em prática os ensinamentos que os poucos adultos lhes transmitiam.

Não obstante as narrativas circularem em um ambiente aparentemente limitado, restrito a poucas pessoas, as estórias fazem parte do imaginário coletivo e em geral oportunizam vínculos entre os indivíduos, por serem prazerosas. Entre tantas que Miguilim ouvia, o repertório de "seo Aristeu" estava entre as suas preferências: "Miguilim desejava tudo de sair com ele para passear - perto dele a gente sentia vontade de escutar as lindas estórias" (ROSA, 2001, p. 78). Entretanto, esses momentos de deleite também serviam para instigar a imaginação do menino, e "sempre pensava em seo Aristeu - então vinha a ideia de vontade de poder saber fazer uma estória, muitas, ele tinha!" (ROSA, 2001, p. 82). Ao lembrar-se do amigo, o protagonista reportava-se às estórias que ele contava e daí a vontade crescente em desenvolver a mesma habilidade. Nesse sentido, interagem a memória em geral e a memória autobiográfica. Nas memórias da personagem principal, o desejo estava centrado na magia de conseguir, também, aprender a contar estórias, uma necessidade inerente aos seres de linguagem.

Outro sentido evocado por Miguilim em suas memórias é o olfato, embora se saiba que "podemos nos lembrar de maneira vívida o perfume de uma flor [...] mas a lembrança não é igual à realidade. A memória do perfume da rosa não nos traz a rosa" (IZQUIERDO, 2011, p. 20). Porém, o menino exercitava essas sensações prazerosas, quando lembrava que "o couro da mala cheirava muito gostoso" (ROSA, 2001, p. 130) ou, durante as capinas, "os pés pisando no matinho cortado. Dava o cheiro gostoso, de terra sombreada. [...] ah! Então nunca ia poder ter um lugar assim, permanecia só aquele fulgorzinho na memória" (ROSA, 2001, p. 142). 
Recordações como essa, no ambiente turbulento da casa onde vivia, traziam alegria e certo alento a Miguilim. Trata-se de uma sensação de certo conforto, possibilidade para poder viver um pouco melhor, já que seu destino seria, talvez, o de permanecer naquele lugar.

As memórias de Miguilim também estavam relacionadas à outro sentido: o tato. $\mathrm{O}$ menino pôde experimentar as sensações deliciosas que o toque das mãos provocava, pois, "Drelina pegara uma das mãos dele, de junto carinhava Miguilim, na testa. Drelina era bonita de bondade" (ROSA, 2001, p. 76). Naquele espaço em que viviam, eram raros os momentos das carícias, do afago e dos abraços. Frequentemente era a violência que imperava, as palavras rudes e provocadoras. Mas existiu outro instante feliz, que Miguilim conseguiu evocar:

Mãitina gostava dele, por certo, tinha gostado, muito, uma vez, fazia tempo, tempo. Miguilim agora tirava isso, da deslembra, como as memórias se desentendem. [...]Ah, se lembrava. Pois porque estava pondo ele no colo, macio manso, e fazendo carinhos, falando carinhos, ele nem esperava por isso, isso nem depois nunca tinha acontecido. O que Mãitina falava: era no atrapalho da linguagem dela, mas tudo de ninar, de querer-bem.[...]A linguagem dela era até bonita, ele entendia que era só de algum amor. (ROSA, 2001, p. 61)

A mãe também era uma pessoa amorosa com os filhos, porém, esses tinham sido alguns dos raros episódios que o menino conseguia se sentir à vontade naquele espaço do Mutúm. Normalmente, suas memórias estavam impregnadas de tristeza, descaso e um forte sentimento de que não poderia pertencer àquele lugar.

Miguilim tinha medos, como qualquer criança. Não possuía somente temores do pai e das intempéries do tempo. A noite também o amedrontava, porque "pode ser um lapso de abandono e de medo para a criança" (BOSI, 1999, p. 417). O sentimento do menino, em relação à hora de dormir, era uma mistura de várias percepções e os sentidos ficavam aguçados, na espreita de que algo fosse acontecer. O protagonista adormecia por último, o que piorava a sensação de pavor da noite:

Dito começava a dormir de repente, era a mesma coisa que Tomezinho. Miguilim não gostava de pôr os olhos no escuro. Não queria deitar de costas, porque vem mulher assombrada, senta na barriga da gente. Se os pés restassem para fora da coberta, vinha mão de alma, friosa, pegava o pé. (ROSA, 2001, p. 50) 
A única sensação agradável vinha do olfato, pois o "travesseiro cheirava bom, cheiro de macela-do-campo" (ROSA, 2011, p. 50). Durante a noite, o protagonista, por vezes, evocava as memórias para relembrar do tio Terêz e de um dia, em particular:

Um dia, tempos, Tio Terêz o levara à beira da mata, ia tirar taquaras. A gente fazia um feixe e carregava. “- Miguilim, este feixinho está muito pesado para você?" "-Tio Terêz, está não. Se a gente puder ir devagarinho como precisa, e ninguém não gritar com a gente para ir depressa demais, então eu acho que nunca que é pesado..." (ROSA, 2001, p.50)

As lembranças das saídas e das brincadeiras com seu tio Terêz sempre eram prazerosas, e o sobrinho sempre se lembrava delas, visto que a " memória das coisas e memória de mim mesmo coincidem: aí encontro também a mim mesmo, lembro-me de mim, do que fiz, quando e onde o fiz e da impressão que tive ao fazê-lo" (RICOEUR, 2012, p. 110). Esse parente representava o amor, o companheirismo e a amizade que o menino não encontrava na figura paterna e que tanta falta fazia. Um vazio que ninguém poderia preencher. E, além do desafeto e da incompreensão encontrados no próprio lar, o lugar não lhe parecia acolhedor. Pouco enxergava, apresentava deficiência visual, entretanto, seus parentes jamais se aperceberam disso. Pensavam que ele era desajeitado, preguiçoso, que não "prestava" para o serviço e, tampouco, parecia ser da mesma família, como o pai muitas vezes declarava. Mas durante a passagem de um médico, pelas bandas do Mutúm, a vida de Miguilim começava a mudar:

De repente lá vinha um homem a cavalo. Eram dois. Um senhor de fora, o claro da roupa. Miguilim saudou, pedindo a benção. $\mathrm{O}$ homem trouxe o cavalo cá bem junto. Ele era de óculos, corado, alto, com um chapéu diferente, mesmo. [...]Miguilim queria ver se o homem estava mesmo sorrindo para ele, por isso é que o encarava.- Por que você aperta os olhos assim? Você não é limpo de vista? Vamos até lá. Quem é que está em casa?- É mãe, e os meninos... [...]O senhor perguntava à Mãe muitas coisas do Miguilim. Depois perguntava ele mesmo: “- Miguilim, espia daí: quantos dedos da minha mão você está enxergando? E agora? Miguilim espremia os olhos. Drelina e a Chica riam. Tomezinho tinha ido se esconder. Este rapazinho tem a vista curta. Espera aí, Miguilim... (ROSA, 2001, p. 148-149)

Com um simples exame de visão, o médico percebeu o que acontecia com o menino. Era a ciência, a medicina que chegava naquele lugar e poderia corrigir um problema simples como aquele, se não fosse tão 
distante de qualquer meio civilizado. Assim, "o senhor tirava os óculos e punha-os em Miguilim, com todo o jeito" e disse “- Olha, agora!” (ROSA, 2001, p. 149). E "Miguilim olhou. Nem não podia acreditar! Tudo era uma claridade, tudo novo e lindo e diferente, as coisas, as árvores, as caras das pessoas. Via os grãozinhos de areia, a pele da terra, as pedrinhas menores, as formiguinhas passeando no chão de uma distância" (ROSA, 2001, p. 149). Naquele instante, um novo espaço era apresentado a ele. O lugar feio, triste, agora era dotado de belezas e pormenores jamais vistos ou sequer imaginados. Do que não podia ver perfeitamente, valia-se das impressões alheias, por isso não possuía uma memória visual que registrasse suas próprias impressões. Usava os demais sentidos para aprender, perceber o que se passava ao seu redor, além da intuição.

O doutor José Lourenço, após uma conversa com a mãe de Miguilim, percebeu que poderia ajudar o menino, levando-o para a cidade. $\mathrm{O}$ convite partiu do próprio médico. A mãe se encarregou de estimulá-lo: "Disse que, você querendo, Miguilim, ele junto te leva... - O doutor era homem muito bom, levava Miguilim, lá ele comprava óculos pequenos, entrava para a escola, depois aprendia ofício. "- Você mesmo quer ir?" (ROSA, 2001, p. 150). O menino estava convencido. Mesmo assim, foi difícil a separação. Afinal, suas memórias, ainda que ofuscadas pela falta de visão, foram preenchidas pelos demais sentidos, além, é claro, da própria memória coletiva. Essa, encarregava-se de suprir, abastecer de sensações, de aprendizado, a memória individual de Miguilim. Juntas, formavam uma memória coletiva e compartilhada, já que "laços, geralmente culturais ou de afinidade e, com base em nossas memórias comuns, formamos grupos: comarcas, tribos, povos, cidades, comunidades, países" (IZQUIERDO, 2011, p. 13).

Assim, o jovem menino partia em busca de um novo lugar para viver. Mas antes, tinha necessidade de "rever" o Mutúm. Pediu os óculos ao doutor e ficou deslumbrado com o que via. Não eram essas as memórias que guardava do lugar:

Miguilim olhou para todos, com tanta força. Saiu lá fora. Olhou os matos escuros de cima do morro, aqui a casa, a cerca de feijão-bravo e são-caetano; o céu, o curral, o quintal; os olhos redondos e os vidros altos da manhã. Olhou mais longe, o gado pastando perto do brejo, florido de são-josés, como um algodão. $\mathrm{O}$ verde dos buritis, na primeira vereda. O Mutúm era bonito! Agora ele sabia. [...] Olhava mais era para mãe. Drelina era bonita, a Chica, Tomezinho. Sorriu para Tio 
Terêz: - "Tio Terêz, o senhor parece com o Pai..." (ROSA, 2001, p. 151-152)

A partir dessa verdadeira redescoberta do ambiente, Miguilim poderia, finalmente, ter opinião própria a respeito do local que vivia com seus parentes e agregados. Não era mais inteiramente dependente das memórias visuais alheias. Agora, possuía as suas, e isso se constituía em algo muito favorável a ponto de o menino expandir a afeição que dedicava a Tio Terêz e, agora, também ao pai, verificando entre os dois adultos certa semelhança. Em continuidade ao reconhecimento das pessoas e do espaço, pediu os óculos para poder registrar na memória as novas impressões sobre a localidade, a aparência da mãe, a quem amava tanto, dos irmãos e do tio. Usou desse subterfúgio para não se esquecer de suas origens, do lugar de onde vivera até então. A casa havia se transformado em lar, após a morte de seu pai. Tio Terêz tomava conta da propriedade e da família. Porém, o mundo era vasto e novos horizontes o esperavam, pois diferentes lembranças ainda seriam gravadas na memória de Miguilim, ao mesmo tempo em que o passado poderia ser trazido à tona, a qualquer tempo, quando evocado.

\section{CONSIDERAÇÕES FINAIS}

A capacidade de armazenar informações, de memorização, é inata ao ser humano. A memória começa a ser construída, já na primeira infância, embora seja difícil expressá-la através de palavras, nessa fase da vida. Mesmo assim, ficam registrados, na memória, os momentos mais significativos. Essa função mental é visualizada, também, através das lembranças da personagem principal, o Miguilim. O menino consegue evocar suas recordações mais antigas, ainda que fragmentadas e distorcidas pela passagem do tempo. Entretanto, é com o auxílio das lembranças da mãe que, unidos, formam uma memória socializada. Mas essa memória entre mãe e filho não pode ser considerada coletiva, uma vez que ela não pertence somente aos dois. Trata-se da memória composta pelo repertório das estórias vivenciadas, numa espécie de comunhão de ideias, de memórias comuns. Pelo fato de que eles vivam em um lugar distante de tudo, as estórias por eles vividas, os ensinamentos, a fé e as desventuras serão repassadas, ainda que sempre em processo de mudança, aos demais, geração após geração. Não serão histórias oficiais, porém, possuem vínculo com a comunidade local, estão enraizadas e se propagam em muito pela 
oralidade em comunidades, como essa do Mutúm, distantes do aparato tecnológico dos grandes centros urbanos.

Miguilim, por sua tenra idade, talvez não tivesse se dado conta da necessidade de se preservar as memórias, muito embora gostasse de evocá-las, sempre que podia. Valia-se, muitas vezes, conforme antes aqui se observou, de todos os cinco sentidos para conservar suas estórias que iriam compor as memórias. Somados, esses sentidos tinham a missão de suprir ou de pelo menos de minimizar a falta de visão do Miguilim, que não compreendia o que se passava com ele. Entretanto, não era pela carência de visão que o protagonista deixava de vivenciar as suas experiências e a dos outros. Muito pelo contrário. As demais percepções estavam mais fortemente preparadas para suprir a carência visual, pois o que realmente o fazia sofrer era a intolerância provinda do pai, e os castigos infligidos ao menino nas contínuas repreensões, no isolamento e na falta de liberdade quando o colocavam sentado a um tamborete.

Assim, observou-se que o protagonista era um menino sensível, que percebia tudo o que se passava ao seu redor, mesmo com dificuldades visuais. A própria casa onde vivia desempenhava um papel importante na consolidação das memórias

A crença religiosa e a fé dos habitantes do Mutúm atestam que as raízes profundas no imaginário popular se instalam mesmo entre famílias que pouco se comunicam entre si. Na família de Miguilim, as pessoas acreditavam que a reza e as crendices populares tudo podiam curar ou resguardá-los de qualquer mal. Daí a necessidade do oratório dentro de casa, para protegê-los das fortes tempestades, de sacrificar um animal para salvar a vida de Miguilim, e do medo que a criança sentia do escuro, na hora de dormir. Essas e outras situações marcavam a trajetória das personagens, principalmente a do protagonista que, mesmo sendo muito jovem, já percebia a situação desfavorável em que vivia. Perspicaz, a criança não só registrava os acontecimentos, receoso já dos grandes enigmas que assolam a humanidade, indagava-se sobre a morte, e também refletia sobre a situação das "mulheres da vida", de que ouvia falar, embora não compreendesse o mundo adulto e dessas pessoas recebesse respostas evasivas ou incoerentes.

Com a chegada da ciência, na pessoa do médico, a vida transformou-se. Miguilim, ao experimentar os óculos do doutor, percebeu que o lugar onde vivia, realmente possuía as belezas de que ouvira falar, através dos relatos. Confirmou que a mãe e a irmã eram formosas. Até descobriu 
que o Tio Terêz se parecia com o pai. Mas aquele lugar, o Mutúm, era pequeno demais e não podia oferecer nada além do que se apresentava. Por isso, Miguilim partiu, incentivado pela mãe. Entretanto, as estórias do lugar e dos parentes ficariam gravadas para sempre em sua memória.

\section{MEMORIES OF PLACE FOR THE CHARACTER MIGUI- LIM IN CAMPO GERAL, BY GUIMARÃES ROSA}

\section{ABSTRACT}

This article brings up a reflection on the construction of the memories of an infant character, in a fictional narrative, influenced by his relatives' collective memories. The reading of the tale Campo Geral (2001) by João Guimarães Rosa, raises such discussion, based on the protagonist called Miguilim, a very sensitive little boy who sees everything through his sensible perceptions and reports from those who live along with him, to build up his own memory and to start his understanding upon his surroundings. It is through the external signals, the spatial and collective memories that this character builds and destroys his family and his own story. The protagonist evokes his memories to create a connection between his feelings and reality around him, even if such memories come from an extremely young mind and also, a little inexperienced. Focused on the comprehension of the memories building process during this part of one's life, it becomes necessary to call some technical support of the authors Iván Izquierdo (2011), memory study under the neuroscience perspective, Alan Baddeley (2011) and his collaborators who do research on the memory building and Maurice Halbwachs (2015), who establishes relation between memory acquisition and social context. Besides such specialists, researchers as Doreen Massey (2008) and Gaston Bachelard (w/d) have also contributed with their studies by reflecting about the importance of place and space. Throughout these theories' fra- 
meworks, we can grasp some forms for the acquisition and keeping of the infant memory.

KEYWORDS: Feeling; space; place; individual and collective memory; Campo Geral.

\section{REFERÊNCIAS}

BACHELARD, Gaston. A Poética do Espaço. Trad. Antônio da Costa Leal e Lídia do Valle Santos Leal. Rio de Janeiro: Livraria Eldorado Tijuca Ltda, (s/d).

BADDELEY, Alan. In: BADDELEY, Alan; ANDERSON, Michael C.; EYSENCK, Michael W. Memória. Trad. Cornélia Stolting. Porto Alegre: Artmed, 2011. Cap. 5, p. 107-127; Cap. 7, p. 152-177.

BOSI, Ecléa. Memória e sociedade: lembranças de velhos. 7. Ed. São Paulo: 1999. CHEVALIER, Jean; GHEERBRANT, Alain, (Orgs.). Dicionário de símbolos (mitos, sonhos, costumes, formas, figuras, cores, números). Coord. Carlos Sussekind. Trad. Vera da Costa e Silva...[et al]. 27. Ed. Rio de Janeiro: José Olympio, 2015.

EYSENCK, Michael W. In: BADDELEY, Alan; ANDERSON, Michael C.; EYSENCK, Michael W. Memória. Trad. Cornélia Stolting. Porto Alegre: Artmed, 2011. Cap. 6, p. 128-151; Cap. 12, p. 285-310.

HALBWACHS, Maurice. A memória coletiva. 8. ed. Trad. Beatriz Sidou. São Paulo: Centauro, 2015.

IZQUIERDO, Ivan. Memória. 2. ed., ver. e ampl. Porto Alegre: Artmed, 2011.

MASSEY, Doreen. Pelo Espaço Uma nova política da espacialidade. Trad. Hilda Pareto Maciel; Rogério Haesbaert. Rio de Janeiro: Betrand Brasil, 2008.

RICOEUR, Paul. A memória, a história, o esquecimento. 5. reimp. Trad. Alain François... [ et al]. São Paulo: Editora Unicamp, 2012.

ROSA, João Guimarães. Manuelzão e Miguilim (Corpo de baile). 11. ed. Rio de Janeiro: Nova Fronteira, 2001.

Recebido em: 26 de junho de 2016

Aceito em: 16 de novembro de 2016 